\title{
THE REDUCED NORMATIVE PROGRAMMING OF ENVIRONMENTAL PROTECTION LAWS IN BRAZIL AND THEIR POORLY ORGANIZED METHODICALLY INTERPRETATION
}

\author{
Andreas J. Krell \\ Doctor Juris at Freie Universität Berlin \\ (Germany). Titular Professor in Environmental \\ and Constitutional Law at the Law School of \\ Federal University of Alagoas (FDA/UFAL). \\ CNPq fellow researcher (PQ - Level 1A).
}

\begin{abstract}
The article addresses an issue poorly discussed by the Brazilian Environmental Law, namely: its low legislation normative programming level. An analysis of legal texts about fields such as licensing shows that formal laws have only few rules that drive clear decisions about conflicts due to conflicting interests. Rules that open wide discretionary room for the interpretation/application of managerial and judicial bureaus often prevail. A documental, bibliographic and jurisprudential research will show that lack of minimum hermeneutical reasoning standard in doctrine and jurisprudence, whose content mostly depends on the individual convictions of public agents judging the claim, causes low decision predictability. The act of weighing the principles follows a rational argumentation line and impairs juridical safety. It would be useful and viable to revalorize classical elements of Law interpretation in combination with modern constitutional hermeneutical techniques in order to replace a complex "environmental hermeneutics".
\end{abstract}

KEYWORDS: Normative programming; environmental laws; juridical interpretation methods; juridical-environmental hermeneutics.

RESUMO: O artigo versa sobre um problema pouco discutido no Direito Ambiental brasileiro: o baixo nível de programação normativa da legislação. Uma análise dos textos legais demonstra que, em áreas como o licenciamento, as leis formais contêm poucas regras que já tomam decisões claras sobre os conflitos de interesses colidentes, prevalecendo normas que abrem largos espaços discricionários para a interpretação/aplicação dos órgãos administrativos e judiciais. Baseado num levantamento documental, bibliográfico e jurisprudencial, será mostrado que a falta de um padrão mínimo de raciocínio hermenêutico na doutrina e na jurisprudência causa uma baixa previsibilidade das decisões, cujo conteúdo depende em grande parte das convicções individuais do agente público que julga o caso. A ponderação de princípios não segue uma linha racional de argumentação, prejudicando a segurança jurídica. No lugar de uma complexa "hermenêutica ambiental", seria mais útil e viável a 
revalorização dos elementos clássicos da interpretação do Direito, combinados com as técnicas modernas da hermenêutica constitucional.

PALAVRA-CHAVE: Programação normativa; leis ambientais; métodos de interpretação jurídica; hermenêutica jurídico-ambiental.

SUMMARY: 1 Introduction 2 The European model of Environmental State: can it be transferred to Brazil? 3 Low normative programming as characteristic of the Brazilian environmental legislation 4 The political profile of judicial decisions about the environment and the interpretation of juridical principles 5 Stagnation of discussions about the use of juridical interpretation methods 6 Rational reasoning, understanding and juridical method: likelihood of a juridical-environmental hermeneutics 7 Final considerations 8 References

\section{Introduction}

Antônio Herman Benjamin, who is a member of the Superior Court of Justice (SCJ), in decision issued in 2007 stated that Brazilian judges "do not create obligations for environmental protection" because such an obligation "flows from law". Thus, it would be unnecessary to have "activist judges" in this field, since activism would come straight from the laws and from the constitutional text. According to the aforementioned Minister, the Brazilian Judiciary "is not haunted by a sea of gaps or by a whole set of legislative halfwords". He concludes that "if there is a gap, it is not so because of the law, not even because of a flaw in the law", but "because of lack or shortage of managerial and judicial implementation in unmistakable environmental duties established by the legislator" (STJ REsp n. 650728-SC).

There is no doubt that the environmental legislation in Brazil nowadays is relatively well-formed and can be considered "modern", but little effective, given, for instance, deforestation, water pollution or bad management of domestic waste in many regions in the country, which happens despite the laws in force. There are different factors of political, socioeconomic and cultural nature capable of explaining such an "execution shortage", among them one finds lack of technical capability by environmental bureaus, corruption among the involved public agents, the influence of economic actors on politicians and managers, the traditional mix between public and private interests, among others.

However, we dare to somehow disagree with the praiseworthy allegation by Minister Benjamin about the structuring of the Brazilian environmental legislation that, in several points, is bad shaped, which contributes to its misinterpretation. We understand that there is defective legal programming of a significant part of decisions made by public bureaus in the environmental protection field, which, sometimes, lead to an insufficient dogmatic reasoning about the coexistence of, and links between, the subsumption of rules and weighting of principles. Furthermore, there is little clarity about the association between juridical and political elements guiding the hermeneutical process in a field of diffuse interests, mostly of the right to a healthy environment.

Going opposite ways to the aforementioned words, Roberto Mangabeira Unger, Associated Professor in Harvard University Law School (USA) and former Minister in Chief of the Secretariat for Strategic Affairs of the Presidency (during Dilma Rousseff's administration), stated, in July 2015, that the real problem of the Brazilian Environmental Law would not be its excessive demands, but the fact that it consisted in "a pseudo-Law, almost entirely processual", based on the principle of prevention, which could only work

4 | Revista Brasileira de Direito Animal, e -issn: 2317-4552, Salvador, volume 15, n. 03, p.3-17, Set - Dez 2020 
"when [it would be] turned into a set of rules". Instead of such rules, there would be "a delegation of almost unlimited discretionary powers given to a group of small managerial potentates". The application of abstract principles without setting concrete "rules for the game" would lead to the "pure subjectivity" of Law operators and make an "invitation to replace the juridical ordering by an open conflict between ideologies and interests". ${ }^{1}$

Even if one does not fully agree with this rough evaluation about the national Environmental Law, it is paramount acknowledging that the critic made by the former Minister is not empty, but concerns the flaws and problems (little mentioned) of this concrete juridical branch, which will be addressed next.

A documental (bill), bibliographic (national and foreign doctrine) and jurisprudential (decisions issued by the superior courts about methodical matters concerning the interpretation of Law) research will show that lack of a minimum hermeneutical reasoning standard about the doctrine and jurisprudence in Brazil has been leading to reduced predictability about decisions issued in the environmental protection field, whose content mostly depends on individual convictions of public agents judging the claim.

\section{The european model of environmental state: can it be transferred to brazil?}

At first, it is possible questioning whether the European model of Environmental State can be transferred to Brazil. In Europe, the risks posed by nuclear power, genetic research and climatic changes gave birth to doubts about the function of democraticrepresentative instruments of the Rule of Law. It was clear that traditional institutional structures must be enhanced in order to broaden the acceptance of decisions by the population. At the same time, the establishment of an Ecological Constitutional State presupposes the creation of institutions appropriate to its functioning, otherwise, it would only have a symbolic profile.

Industrialized countries nowadays face the great challenge of constitutionalism, which is no longer centered in social matters, but in citizens' preventive protection from the negative effects of technical progress, i.e., risk prevention. ${ }^{2}$ With respect to Brazil, the term Environmental State does not have a quite expressive secondary meaning, since the State did not take the environmental issue as new parameter for its decisions. It is clear that there was no "change of paradigm" in this particular issue. The legislation about the power of State still does not depend much on the question about whether it effectively accomplishes the constitutionally established task of protecting the environment due to several socio-cultural reasons. ${ }^{3}$

The path taken by the modern Constitutional State in Europe started from the Liberal Rule of Law, passed through the Social State and is now getting to the Environmental State. ${ }^{4}$ Latin-American countries do not have political and institutional experience in a reasonably effective Social State and it impairs Environmental State formation. Accordingly, it is also possible questioning the very intention of the Brazilian State in leading the environmental protection field, since the managerial bureaus sometimes still take actions against the legislation, mainly when it comes to the approval of politically important projects, such as the infrastructure ones (dams, harbors, roads, among others).

Several environmental rules in force work as alibi and aim at bringing immediate satisfaction to the population. Other rules are the expression of a political commitment and anticipate decisions about conflicting interests. Yet, these rules can be under the sign

5 | Revista Brasileira de Direito Animal, e -issn: 2317-4552, Salvador, volume 15, n. 03, p.3-17, Set - Dez 2020 
of a pre-set "execution shortage", in other words, the legislator predicts and accepts that the rule cannot be effectively applied. ${ }^{5}$

Furthermore, we see that legal changes that have downgraded the previously reached protection level, such as the case of the 2012 Forest Code, of the Constitutional Amendment (CA) that legalizes practices such as rodeos (against decision issued by the Supreme Court), of the CA that intends to change the competence of Environmental Impact Assessment (EIA) for ventures proposed by the Public Power or of Federal Bills concerning environmental licensing (added with a list of exempt activities).

Most of all, it is possible questioning how the bureaucratic tradition and political culture in Brazil would allow a bonding orientation to public bureaus about preventive protection and precaution against ecological risks, since these initiatives are often limited to the scope of traditional prevention against hazards. So far, there was no "greening" of local, regional and national political agendas due to the traditional dispersion of vertical (federative) and horizontal (sectorial) competences. Moreover, population participation in decisions made about ecologically sensitive issues inherent to the Environmental State ("sustainable democracy", "environmental governance") seem to be far from reality in the big Brazilian cities.

The more or lesser significant distance between constitutional rule (art. 225) and social reality enables the constitutional rule to become a political action parameter, as well as its further evaluation. Thus, the constitutional text has important symbolic power, which is capable of encouraging deeds heading towards ecological values that influence the juridical sense of society in the long-run. ${ }^{6}$ The normative and empirical constitutions are in a mutual-effect position: the intention can only be accomplished if, and to the point that, certain extra-judicial factors are performed. Therefore, according to Hesse, it seems that many decision-makers in Brazil - politicians, public agents and civil society representatives - are not really "prone to Ecological Constitution".

At the same time, the precarious social conditions open room for the questioning about whether the Brazilian jus-environmental doctrine would not do better if it was concentrated in the need for stricter protection rules and in the intense participation of society, rather than dealing with a "new ecological paradigm". ${ }^{7}$ Besides, the socioeconomic context recommends the adoption of the socio-environmental model, whose greatest challenge lies on generating convergence between social and environmental agencies in order to achieve a unified jus-political project aimed at sustainable human development. ${ }^{8}$

\section{Low normative programming as a characteristic of the brazilian environmental legislation}

Overall, the Brazilian environmental laws account for few clear valuing based on rules that encompass well-defined concepts. They leave the weighing fulfilment of conflicting interests - general public interest and specific diffuse interests - at the hands of managerial bureaus (monocratic or collegiate), mainly of the Courts. The Federal law on Water Resources (n. 9.433/97), Biosafety (n. 11.105/05), Research with Animals (11.794/08), Biodiversity (13.123/15), and on the Resolution issued by the National Environment Council about the Environmental Impact Assessment (001/86), as well as the laws on environmental licensing in many states are some examples of the statement above.

Lack of more concrete legal predictions about the solution for conflicts of interest in a myriad of repetitive claims makes it hard to public and diffuse interests, within the

6 | Revista Brasileira de Direito Animal, e -issn: 2317-4552, Salvador, volume 15, n. 03, p.3-17, Set - Dez 2020 
discretionary spaces of managerial bureaus, to produce normative power. In other words, the positive Law hardly contributes to determine the content of such interests. ${ }^{9}$

Oftentimes, a juridical ordering declares certain interests as worth protection and preference to the detriment of others and end up making decisions about typical conflicts. Wherever it does not happen, it is not very clear why Law has to oppose several interests that involve society. In this situation, the Law "loses much of its dogmatic strictness and conceptual controllability", therefore, "a juridical decision cannot be reduced to a mere weighing of interests" ${ }^{10}$ However, this is the very decision-making trend in several fields of the Brazilian Environmental Law.

Little was discussed so far about the weak "normative programming" of Brazilian environmental laws. The Congress (or local Parliaments) should better standardize the risk dimensions, and complexity and future effects of decisions made about the use of technologies capable of influencing the life of future generations. The principle of "reserve of the law", although acknowledged by the Brazilian constitutionalism as the result from the Rule of Law, has been violated by countless rules that transfer the regulation of essential subjects about fundamental rights to the Executive power or even to nongovernmental entities, without fixing considerations and clear limits. ${ }^{11}$

Such lack of programming reduces the predictability about decisions and the necessary interpretation/application of it, in other words, the framing of facts concerning normative predictions hardly refer to the respective terms (more or lesser determined) by the hypothesis or by the pace of the legal provision of Parliament itself. However, the evaluation of dangers and risks in the environmental field, as well as the fixation of reference values and standards to the appropriate management of natural resource also represent a political matter and shall not be treated as a merely technical-bureaucratic subject. $^{12}$

Brazilian lawmakers do not use to reduce the spaces for decisions about important matters through the introduction of the respective juridical concepts in the text of laws, mainly when it comes to politically sensitive fields like the licensing of projects and activities potentially hazardous to the environment. Instead of the prescription of concrete conditions for issuing licenses, formulating the conditions or repealing such prescriptions, one often finds rules about the competences, management procedures and some prohibition in the laws in force.

Bill n. 3.729/04, from $2004,{ }^{13}$ is good to exemplify the low normative programming, it addresses environmental licensing and Environmental Impact Assessment elaboration. Without deepening the discussion about its content (the polemical prediction about the "simplified process" of licensing), it is worth highlighting that only art. 10 of this Bill establishes material criteria (quite vague) for the issuing of environmental licenses, it states that

The licensor must demand the entrepreneur to adopt measures capable of assuring that raw materials and other inputs, production processes and produced goods have a quality standard and technical procedures that eliminate or reduce their harming effects to the environment.

It is intriguing that the lawmaker did not try to better concretize the items mentioned in the rule (caput) that sets the conditions for license issuing in a bonding way ("the licensor must demand"). It is not clear how "quality standard" and "technical procedures" must be defined, in concrete claims, in order to eliminate or reduce environmental degradation. Again, the responsibility for defining these criteria is being

7 | Revista Brasileira de Direito Animal, e -issn: 2317-4552, Salvador, volume 15, n. 03, p.3-17, Set - Dez 2020 
displaced to the councils, managerial bureaus and technical entities representative of several professional fields. The legal text does not expressly determine a normative delegation towards such criteria.

The new version of Bill n. 3.729, ${ }^{14}$ adopted by the Commission for the Environment and Sustainable Development (CESD) of the Congress, in 2015, states (in its article 14) that the licensor authority, after issuing a technical report able of showing the need for the measures to be taken, can demand the entrepreneur to

I - provide technical maintenance or a team of experts accountable for the venture as a whole, or for just a sector of it, or for a specific action field, in order to assure its environmental adequacy;

II - to make an independent environmental audit of specific or periodic nature, just as addressed by the licensor authority after technical study or consultation to the eventually affected population, as well as to assure the broad outspread of its results; III - analyze the environmental risk and to elaborate the venture's contingency plan as a whole, and if this is the case, of a sector or specific action field;

IV - elaborate a report of accidents during venture implementation and operation, including events that could lead to significant accidents;

$\mathrm{V}$ - elaborate the balance of greenhouse gas emissions, by taking into consideration venture's implementation and operation, as well as minimizing and compensating measures due to such emissions;

$\mathrm{VI}$ - prove the economic-financial capacity of the venture to afford costs resulting from the obligation to recover or rehabilitate degraded areas and to repair personal and material damages eventually caused by the venture to the population or to the public patrimony; and

VII - contract an insurance company of civil responsibility for environmental damage, based on the terms of the resolution issued by the advisory and deliberative organs of the National Environmental System (SISNAMA).

Even if the details of the material conditions in here are lesser vague than those in the initial version of the project, the decision about the requirement for measures to be taken by the entrepreneur has a much more discretionary trend, ${ }^{15}$ since the law bonds its requirement to considerations by the managerial bureau itself about its convenience and opportunity in concrete claims ("the licensor can demand"). Thus, once more, the normative programming of the disposition ends up diluted, even if it is much more outstanding than in the original version.

Furthermore, it would be necessary consolidating and adjusting the rules about Environmental Impact Assessment (EIA) and its Report (RIMA) in a Federal Law of Environmental Licensing, which should establish a stronger normative programming concerning evaluation criteria to be followed by managerial bureaus. The analysis of Bill $n$. 3.729/04 shows that the dispositions concerning EIA-RIMA do not introduce legal concepts, according to which, licensing requests should be approved (or rejected), but they just define the minimum mandatory content of these technical studies and of their

8 | Revista Brasileira de Direito Animal, e -issn: 2317-4552, Salvador, volume 15, n. 03, p.3-17, Set - Dez 2020 
respective reports, with only few changes regarding the rules in force (Resolutions n. 001, from 1986, and n. 237, from 1997, by CONAMA). ${ }^{16}$

It is not common in Brazil for legal texts on environmental licensing - be them at municipal, state or Federal level - to describe the concrete duties to the ones proposing the projects or to demand certain technical qualifications to them. Besides, the laws do not establish material standards to a proportional and reasonable weighing of the most important aspects of the respective conflict situations and do not refer to the "general state of the technique" or to the "best techniques available", as it happens, for instance, in several laws of countries belonging to the European Union.

Accordingly, a perfectionist "over-programming" of managerial decisions made by the parliaments is not herein defended, since it would be an illusion in face of the need for a flexible protection of environmental resources managed by the public bureaus. However, the general unsafety about the ecological risks shall not take to the regulation of material conflicts by the ones elected by the population. Before delegating "open material matters" to specific decision-making procedures put in place by the specialized bureaus, the legal texts of the Congress (or local Parliaments) must establish a basic normative programming structure.

The concept of "procedural Environmental State" must be seen with suspicion within a social environment where there is little exercise of citizenship rights and where one finds a heterogeneous and corporatist society. The formula of the "common good through procedure" (Häberle) still does not find trace in a society in which communication among representatives of the State power, groups of economic interest, associations aiming the environment and interest citizens is precarious, although it could legitimize the results from these procedures. Thus, engaged actors capable of properly putting in force aspects concerning the defense of the environment in managerial processes are scarce in Brazil (for example: EIA/RIMA).

It is also important having in mind that public bureaus can "negotiate" with private actors in a productive way in order to achieve the common good in case they are in a strong and privileged institutional position. Without the power to use legal pressure, they will easily find themselves in a lower position, in which entrepreneurs will understand any concession as expression of weakness and as an "invitation to barriers". ${ }^{17}$

The shortage of legal regulations also stops the formation of a dogmatic and denser Environmental Law, which ends up compelling Law enforcers to once more discuss many juridical matters in the writing of their decisions, since they lack accepted dogmatic reasoning formulas. Most problems concerning the interpretation of environmental rules was not sufficiently analyzed and theoretically clarified. Moreover, countless managerial acts and juridical sentences encompass quite superficial and little convincing argumentation lines. Therefore, they do not work for future claims as precedents that could order the matter.

Thus, it is up for each employee what normative texts, sporadic precedent or doctrinal positions must be chosen in order to form the argumentation basis of its decision, which considerably reduces the predictability of its decisions and increases the chances of corruption, since it is possible advocating for almost any decision about the concrete claim. Therefore, nowadays, it does not make much sense showing contempt towards attorneys at law and "dogmatic" juridical enforcers, assumingly alienated from the social reality. Actually, the real issue lies on the fact that a little mature, superficial and mainly rhetoric dogmatic profile that still does not correspond to the existence of the Rule of Law, prevails in the jus-environmental scenario - as it also happens in other fields of the Brazilian Law. ${ }^{18}$

9 | Revista Brasileira de Direito Animal, e -issn: 2317-4552, Salvador, volume 15, n. 03, p.3-17, Set - Dez 2020 
The accountability for such a dilemma, however, cannot be attributed to the dogmatic profile per se, since it derives from different factors, such as the traditionally formalist juridical teaching, the doctrine's dependence on practical juridical professions or lack of objective and critical academic discussions.

\section{The political profile of judicial decisions about the environment and the interpretation of juridical principles}

The Brazilian Federal Supreme Court (STF) emphasized in a paradigmatic decision from 1995 that due to the

permanent state of tension between the imperative of national development $\left(\mathrm{CF}\right.$, art. $\left.3^{\circ}, \mathrm{II}\right)$, on the one hand, and the need of preserving the integrity of the environment (CF, art. 225), on the other hand, it becomes essential acknowledging that overcoming this antagonistic factor, which is opposite to relevant constitutional values, will depend on concrete weighing of each claim, of interests and rights observed in conflict situations, in order to harmonize them and stop them from annihilate each other, by having as interpretation vector, for the obtainment of a fairer and perfect balance between economic and ecological demands, the principle of sustainable development (...) (ADI-MC $n$. 3540-1/DF, Rel. Min. Celso de Mello).

Similarly, the Superior Court of Justice (STJ) understood, in $2011,{ }^{19}$ that "the environment has legal protection supported by specific principles that assure its special protection" and that "the instruments of legal protection - extra-judicial and judicial - are guided by their basic principles", namely: intergeneration solidarity; among others, they have "application in all orders of work (prevention, reparation and refund)". These decisions, however, so far did not lead to changes heading towards lower instances and based on greater orientation about environmental protection aspects.

The application of juridical principles by Law enforcers hardly take place in a methodically satisfactory way in Brazil, to the present time. The "constitutionalization" of the juridical order led to the situation according to which only few fields of Law do not discuss these principles by weighing and constitutionally filtering ordinary laws. According to Sarmento, this valorization of principles, however, took to a real "methodological anarchy": ${ }^{20}$ the reference - argumentatively disordered and methodologically weakly supported - to countless principles within an unstable juridical and excessively flexible culture contributed to debilitate the already weak appeal for the significant and coherent amplification of laws.

The proper interpretation of constitutional principles within the scope of the juridical methods has been the more intensely discussed theme in the last few years. Given their omnipresence (or "ubiquity") in juridical argumentation, dangers following the exacerbated and little reflected enforcement of principles in juridical interpretations have been standing out. The explicit reference to principles is oftentimes used to veil the use of little convincing arguments and to hide the strong voluntarism in decision-making. The best example of such a dilemma is the principle of dignity of the human person, which uses to be referenced by the jurisprudence and doctrine in order to substantiate diametrically opposite outcomes. Moreover, there was the poorly coordinated and 
predictable application of the principle of prevention/precaution by the Courts, mainly in the environmental protection field. ${ }^{21}$

Several Law interpreters/enforcers do not see that the concretization of principles due to weighing in this confusing hermeneutical medium - in the sense of the theory by Robert Alexy - must guide a formal procedure and fit a rational substantiation structure that has to be combined to traditional juridical methods. This disciplined hermeneutical work, however, is performed by few Law enforcers. Therefore, authors such as Streck argue that the recurrence of principles and their interpretation would have become an invitation for unstoppable subjectivism and to uncontrolled discretion. ${ }^{22}$

Sundfeld states that individuals in juridical professions know quite well judges' will to use principles to build and substantiate their decision, which depends more on matters linked to the political role they are willing to embody in a concrete claim than to rationality. The author highlights that it does not make much sense arguing based on sophisticated and complex juridical theories in discussions in the Court about the normative degree to be attributed to a poorly determined legal concept and about how it should be applied. It is so, because judges would be mostly oriented by practices and would first think about how to substantiate their decision in a simpler way, as well as about what would be the immediate consequences of their verdict. ${ }^{23}$

With respect to the dynamic, mutating and highly conflicting field of rights and diffuse interests, it is easy to find decisions that are the very expression of the political options of the respective interpreters/enforcers. ${ }^{24}$ Although it is useful keeping certain distinction between juridical and political arguments, which are based on different rational justification and legitimation criteria, the radical delimitation between Law and Politics as two "operationally closed systems" encompassing different functions, encodings and programs, ${ }^{25}$ is not much helpful.

On the contrary, it seems to be more adequate to understand the difference between "political" and "juridical" within this context in a gradual-quantitative fashion, rather than in a qualitative one: whereas in political decisions the positive Law only creates the frame in which positions must be justified with arguments, the basis for juridical decisions lie, almost immediately, on the normative predictions of the positive Law. These predictions use to be bond to rules and aim tradition more than innovation, whereas political decisions are based on principle fashioned rules and take into account the social consequences from the decision made. ${ }^{26}$

A typical case of political decisions made by the Brazilian Environmental Law are the ones made by the presidents of Courts in public civil claim to stop injunctions granted by first instance judges in favor of environmental protection. The referred injunction can be determined "in order to avoid severe injury to the order, health, safety and public economy" (art. $12 \S 1$ da Lei 7.347/85). A considerable part of claims in the environmental field is impaired at preliminary stage in favor of influential businessmen or even of public entities (in case of infrastructure projects) due to these decisions.

The weighing among diffuse and public interests, and assets and social values that go against them, uses to be superficial. In most cases, these "monocratically" enforced suspensions anticipate claims' outcomes, without previous in-depth analysis about the material juridical situation by members in the chambers of the Courts. However, the compliance (integrative and ponderous) with indeterminate juridical concepts linked to public interests (public order, public mora, public health, common good) by Courts should be guided by normative evaluations that have already been issued by other public bureaus, but it does not mean that they would have to be necessarily followed.

11 | Revista Brasileira de Direito Animal, e -issn: 2317-4552, Salvador, volume 15, n. 03, p.3-17, Set - Dez 2020 
In order to avoid a political-subjective "decisionism" it is essential having a higher level of rational substantiation guided by juridical methods applied to interpretations and by often accepted argumentation ways. Overall, decisions made in the environmental field concern the weighing of different principles that must attribute homogeneity to the Environmental Law, because the normative texts act in a poorly systematic way and provide few compliant juridical concepts to managerial bureaus.

\section{The stagnation in discussions about the use of methods applied to juridical interpretation}

One of the main reasons accounting for problems linked to the proper application of the Environmental Law by managerial bureaus and Courts lies on the defective orientation provided by the Brazilian juridical doctrine. Nowadays, only few authors productively problematize and discuss the topic about the up-to-date and proper application of juridical methods and of argumentation practices matrices in Law interpretation/application.

Actually, many professionals in this field have considered the traditional methodical questionable or even useless. The military regime (1964-85) is still associated with positivism, dogmatism and deductive subsumption due to traditional methods, as well as to the devaluing of philosophical, sociological, historical and anthropological aspects of the juridical work and of the science of Law as a whole.

The interpretation of the numerous principle fashioned propositions in the 1988 Constitution got to the very core of the attention paid to the doctrine, which refuses the use of classical methods in the constitutional interpretation scope. Such a feature impaired the discussion about the limits and possibilities of proportionality. ${ }^{27}$ Many actors, so far, do not accept that juridical interpretation does not intend to find out the "real" or the "only possible" solution for a given problem, but only searches for a defensible solution in order to inter-subjectively justify it.

Accordingly, the task set for the science of Law is to unfold the reasons why the hermeneutical work of the juridical enforcer can be accepted in some cases, but not in others. The ultimate juridical decision is not an act mostly political or irrational, not even a pure act of the judge's will, but a dimension that naturally belongs to Law and is accessible to a methodical reasoning. ${ }^{28}$

The fact that the most followed theoretical schools and lines of thought in the Brazilian doctrine approach theories that advocate for the position of the observer rather than for that of the participant in the application process is the testimony about the indifference relationship between juridical theory and practice. Thus, many Law enforcers feel lonely in their daily work and migrate to "decisionism", in other words, they do not properly and comprehensibly substantiate their decisions.

With respect to Brazil and to its Law interpretation/application scope, one cannot yet find something that deserves to be called "contemporary juridical hermeneutics" ${ }^{29}$ or to be seen as a certain "basic hermeneutical standard" as observed in other countries. Actually, what mostly prevails in the Public Law scope is something that can be called "conglomerate of transcendental meta-theories". ${ }^{30}$

Some advocate for a deep reorientation of the juridical interpretation towards the philosophical-ontological hermeneutics by Gadamer and Heidegger, others, still inspired by Kelsen's positivism, argue that the teleological method is the pretentious hiding place for the personal opinion of the juridical interpreter or to avoid the reference to values and their weighing - a fact that became common in the Brazilian practice of Law.

12 | Revista Brasileira de Direito Animal, e -issn: 2317-4552, Salvador, volume 15, n. 03, p.3-17, Set - Dez 2020 
There is also the influence of post-modern juridical theories of radical-relativist nature that simply state the effects that all sorts of texts have on their readers as unpredictable, even on the enforcers of juridical rules, which leads to an absurd understanding about the juridical interpretation. However, it is not enough limiting to the formula (almost cynical) "anything goes" in this discussion. Actually, it is necessary carrying out an objective analysis of subjective factors that determine the interpretation, in order to take away the image of unpredictability and contingency from this everyday act. ${ }^{31}$

Based on the aforementioned reasons, the doctrine of the Brazilian Environmental Law still has not been promoting an abstraction good enough to countless conflicts and to their respective juridical decisions, although it emerges as essential for the solution of ubiquitous interpretative issues. Many sectors of this juridical field still lack a constructive dogmatic that aims at putting in systematic and coherent connection the politically made decisions by the legislator and the sentences by Courts about concrete claims. ${ }^{32}$

This dogmatic gap worsen the difficulty faced by managerial bureaus and Courts to apply the vague and little determined concepts of Environmental Law (risk, significant environmental impact, pollution, degradation, prevailing ecological interest, land scape aesthetics, among others) based on the respective claims in a rational and predictable way, by turning them into concrete decisions.

6 Rational substantiation, comprehension and juridical method: possibilities for a juridical-environmental hermeneutics

Method and results are much more entangled in such a complex fashion in the juridical reasoning scope than the traditional logics is willing to admit. There are many evidences about the mutual dependence of both elements on the hermeneutical process. The classical "canon" of methods represents a "sequence of steps about the juridical way of thinking" ${ }^{33}$ and sets a relatively safe measurement that makes it possible introducing reasoning of topic, associative and "consequentialist" nature, in the interpretative process and evaluating it.

Similar to the argumentation rules, juridical methods enable a more intense analytical control, although narrow. Notwithstanding they do not take from Law enforcer the responsibility for making a personal valuing of normative conditions and of the possible consequences from its decisions, the methods set reference points and orientation lines to its interpretations and mark the limits to evaluate their results by others.

Accordingly, methods are the means that make it possible achieving an intersubjectively controllable substantiation of a certain pre-understanding. The justification for a decision in favor or against an interpretation due to an analogy, integration of legal gaps, grammatical or teleological normative elements, pleas to values or recurrence to certain dogmatic constructions or topoi. It does not find answers in the interpretative criteria themselves but cannot be separated from its application.

This prejudice or "pre-judgement" - individually, socially, culturally and professionally conditioned - concerning a claim must be specified through juridical knowledge, doctrine and methodical reasoning. ${ }^{34}$ Furthermore, it should be permanent, questioned, rethought and corrected by the interpreter itself. Analyzing how far this type of critical control goes in Brazil, in practical terms, is not the aim of the current study.

It is not convincing in the juridical interpretation/application scope to make a strict distinction between a "hermeneutical phase" (primary) of the understanding and an "analytical phase" (secondary) of substantiation. ${ }^{35}$ These moments of comprehensive

13 | Revista Brasileira de Direito Animal, e -issn: 2317-4552, Salvador, volume 15, n. 03, p.3-17, Set - Dez 2020 
interpretation and explanatory argumentation of the juridical hermeneutical face a dynamic (or dialectic) reciprocity relationship that paces fast towards "trial and error" and allows punctual correction at any moment. ${ }^{36}$

Within this "set of successive specifications and concretizations", it is essential matching logical-analytical elements to the hermeneutical-valuing ones, which do not represent contradictory dimensions, but the mediating ones. It is on this very way to the understanding that the initial "normative hypothesis" - i.e.: the first approximation of the interpreter to the claim to be decided, which uses to be little transparent and inspired by intuition - is confirmed or denied and, whenever necessary, corrected. This mental process brings along inseparable moments of explanatory justification and understanding. This comprehensive phase certainly is prior to the methodical explanation, it follows and finishes it. However, the explanation itself becomes necessary to trigger and develop the understanding process. ${ }^{37}$

In order to reach the targets of a Socio-environmental State in Brazil, some authors recommend to develop a specific "juridical-environmental hermeneutical" guided by the principles of precaution, sustainability, accountability, solidarity, proportionality and participation, which would have to necessarily dominate the pre-understanding of Environmental Law's interpreters/enforcers. ${ }^{38}$ Thus, a "hermeneutically adequate decision" would have to outspread from each claim to the "ecologization" of the Constitution, whose principles would work lesser to substantiate decisions in the environmental field and more to set the anticipated understanding about the concrete juridical issue. ${ }^{39}$

Although the aforementioned principles are important reference points to the production of adequate decisions, it is possible questioning to which extent the preunderstanding by a rule interpreter is influenced by constitutional principles or by other legal rules. Regardless of their degree of density, normative commandments must be made real by the argumentative justification for a decision to be made. On the other hand, the hermeneutical pre-understanding, which is named by the specific "way of living" or "world view" of the Law interpreter/enforcer, is only indirectly influenced by principles, since such a pre-understanding (and its "pre-judgements") is not formed from reasoning, but is given by general linguistic experience. ${ }^{40}$

Whoever states the pre-understanding as decisive factor for the legal interpretation, does good in paying closer attention to its juridical aspects, even if they are also influenced by philosophical or ideological concepts. The juridical specificity lies right on the obligation of making the right decision and on substantiating it in a pretty convincing way. Besides the normative texts, factors that form the juridical preunderstanding are the knowledge of dogmatic figures and doctrinal opinions, of jurisprudence and of other objective circumstances concerning the problems to be solved, as well as the attitudes and professional viewpoints (lawyer, prosecutor, judge, professor, among others).

Thus, there will hardly be a positive influence on the pre-understanding of the interpreters/enforcer of the Brazilian Environmental Law until the dogmatic and the theory of methods of the country make the adequate means available to justify the juridical elements of these pre-judgements and to limit them in a differentiated way, in order to "integrate them to the concretization process as structuring, controllable and discussible factor". ${ }^{41}$ 


\section{Final consideration}

So far, part of the indoctrinators of the Brazilian Environmental Law considers the "ecological rights" as self-evident and assured by its own enforcement, without the need of questioning its interpretation/application and effectiveness, or of looking for better theoretical and dogmatic explanations. However, the Environmental Law is a discipline that, in order to do not become an empty speech, must always enquire about the effective outcomes from the application of provisions of ordinary environmental laws and of the Constitution. $^{42}$

The juridical hermeneutical would do good if it once more approached and problematized the traditional methodical by better working a new connection between the classical methodical canon and the different argumentation forms to substantiate the decisions made. The problematic concerning the application of weighing forms of reasoning and argumentation in the interpretation of indeterminate juridical concepts inserted in legal texts would also deserve closer attention. ${ }^{43}$

Decisions by managerial bureaus and Courts in the environmental field must be made in a methodologically clean way. That is the only way through which protective legal rules will be applied in a reasonably predictable and understandable way. Its intense orientation towards interests, principles, weighing and discretion did not bring, to the present times, great advantages to the Brazilian Environmental Law, since there was no sufficient dogmatic definition to its concepts and instruments.

Yet, the sparse decisions made by State bureaus in favor of the environment mainly concerning significant projects and activities potentially polluting - are mostly motivated by the subjective-personal attitude of the respective interpreter/enforcer; therefore, they are often suspended or canceled by higher instances.

This confusing framework on the interpretation of laws to protect the environment are inserted in a scene of obstructed communication between juridical practice and doctrine, mainly in fields of the theory of Law and of its methods. It is demanding to have a "pragmatic turning point" in order to guide the Environmental Law outwards the dead end it got to in the last few years.

\section{References notes}

\footnotetext{
${ }^{1}$ UNGER, Roberto Mangabeira. Crítica ao pensamento jurídico brasileiro. Entrevista com Felipe Seligman. Jota, 13.7.2015. Available in: https://jota.info/especiais/critica-ao-pensamento-juridicobrasileiro-segundo-mangabeira-unger-13072015. Accessed: 15.3.2017.

${ }^{2}$ GRIMM, Dieter. Ursprung und Wandel der Verfassung. In: ISENSEE, J.; KIRCHHOF, P. (Eds.).

Handbuch des Staatsrechts der Bundesrepublik Deutschland. Bd. 1. Heidelberg: C. F. Müller, 2003, p. 28 s.

${ }^{3}$ CALLIESS, Christian. Rechtsstaat und Umweltstaat. Tübingen: Mohr Siebeck, 2001, p. 30s., 68, 99.

${ }^{4}$ APPEL, Ivo. Staatliche Zukunfts- und Entwicklungsvorsorge. Tübingen: Mohr Siebeck, 2005, p. 54s., 123 ss.

${ }^{5}$ NEWIG, Jens. Symbolische Umweltgesetzgebung. Berlin: Duncker\&Humblot, 2003, p. 49ss.; NEVES, Marcelo. A constitucionalização simbólica. São Paulo: Acadêmica, 1994, p. 32ss.

${ }^{6}$ ROTHENBURG, Walter C. A Constituição ecológica. In: KISHI, Sandra et al (Orgs.). Desafios do Direito Ambiental no século XXI. São Paulo: Malheiros, 2005, p. 820s.

${ }^{7}$ BOSSELMANN, Klaus. Der ökologische Rechtsstaat: Versuch einer Standortbestimmung. In: BAUMEISTER, H. (org.). Wege zum Ökologischen Rechtsstaat. Taunusstein: E. Blottner, 1994, p. 53ss., 69s.

${ }^{8}$ SARLET, Ingo; FENSTERSEIFER, Tiago. Estado socioambiental e mínimo existencial (ecológico?). In: SARLET, I. (org.). Estado socioambiental e direitos fundamentais. Porto Alegre: Livraria do
} 
Advogado, 2010, p. 16s., 28ss.; AYALA, Patryck. Devido processo ambiental e o direito fundamental ao meio ambiente. Rio de Janeiro: Lumen Juris, 2011, p. 179ss.

${ }^{9}$ HÄBERLE, Peter. Öffentliches Interesse als juristisches Problem. Berlin: BWV, 2006, p. 328ss.

${ }^{10}$ LUHMANN, Niklas. Das Recht der Gesellschaft. Frankfurt a.M.: Suhrkamp, 1995, p. 391 ss.

${ }^{11}$ BINENBOJM, Gustavo. Uma teoria do Direito Administrativo. Rio de Janeiro: Renovar, 2006, p. 150 .

${ }^{12}$ STEINBERG, Rudolf. Der ökologische Verfassungsstaat. Frankfurt a.M.: Suhrkamp, 1998, p. 191ss.

${ }^{13}$ The Bill n. 3.729/04 was proposed by the Dep. Luciano Zica (PT-SP); its third substitute, which creates the General Environmental Licensing Law, is being processed in the Congress with urgency regime and subject to consideration by the Plenary. Available in: <https://www.camara.leg.br/proposicoesWeb/ fichadetramitacao?idProposicao=257161>. Accessed: 8.12.2019.

${ }^{14}$ Available in: <https://www.camara.leg.br/proposicoesWeb/prop_mostrarintegra?codteor= 1400905\&filename $=$ SBT-A+1+CMADS+\%3D\%3E+PL+3729/2004>. Accessed: 8.12.2019

${ }^{15}$ See KRELL, Andreas. Discricionariedade administrativa e conceitos jurídicos indeterminados Limites do controle judicial no âmbito dos interesses difusos. 2. ed. Porto Alegre: Livraria do Advogado, 2013, p. 19ss.

${ }^{16}$ The aforementioned version of Bill 3.729/04 adopted by CESD, of the Congress, in 2015, still addresses the obligation towards the availability of information about the licensing process to the public (through the publication of documents on the Internet) and referring to public hearings and public consultations. About the topic, see SARLET/FENSTERSEIFER, 2018, p. 417ss.

17 APPEL, Ivo. Staatliche Zukunfts- und Entwicklungsvorsorge. Tübingen: Mohr Siebeck, 2005, p. 505.

${ }^{18}$ ADEODATO, João Maurício. A retórica constitucional. São Paulo: Saraiva, 2009, p. 142.

${ }^{19}$ REsp 1.115.555 MG, Rel. Min. Arnaldo E. Lima.

${ }^{20}$ SARMENTO, Daniel. Livres e iguais. Rio de Janeiro: Lumen Juris, 2010, p. 169s.

${ }^{21}$ ANTUNES. Paulo de Bessa. Direito Ambiental. 14. ed. São Paulo: Atlas, 2012, p. 39ss.

${ }^{22}$ STRECK, Lenio. Hermenêutica jurídica e(m) crise. 10. ed. Porto Alegre: Livraria do Advogado, 2011, p. 144ss.

${ }^{23}$ SUNDFELD, Carlos Ari. Princípio é preguiça? In: MACEDO JÚNOR, R.; BARBIERI, C. (orgs.). Direito e interpretação: racionalidade e instituições. São Paulo: Saraiva, 2011, p. 297.

${ }^{24}$ DAWALIBI, Marcelo. Ação civil pública, escolhas políticas e litigiosidade. In: MILARÉ, Édis (org.). Ação civil pública após 25 anos. São Paulo: RT, 2010, p. 595s.

${ }^{25}$ LUHMANN, Niklas. Das Recht der Gesellschaft. Frankfurt a.M.: Suhrkamp, 1995, p. 417ss.

${ }^{26}$ EBERL, Matthias. Verfassung und Richterspruch. Berlin: DeGruyter, 2006, p. 444, 455s.

${ }^{27}$ SILVA, Virgílio Afonso da. Interpretação constitucional e sincretismo metodológico. In: SILVA, V. A. da (org.). Interpretação constitucional. São Paulo: Malheiros, 2005, p. 116ss.

${ }^{28}$ SOUZA NETO, Cláudio P. de. A interpretação constitucional contemporânea entre o construtivismo e o pragmatismo. In: MAIA A. et al (orgs.). Perspectivas atuais da Filosofia do Direito. Rio de Janeiro: Lumen Juris, 2005, p. 475s.

${ }^{29}$ IVR. Abstract Book - XXV World Congress of the International Association for Philosophy of Law and Social Philosophy (Law, Science, Tecnology - Goethe-Universität Frankfurt). 2011, p. 158.

${ }^{30}$ JAHN, Matthias. Pluralität der Rechtsdiskurse - Sektoralisierung der Methodenlehre. In: JESTAEDT, M.; LEPSIUS, O. (orgs.). Rechtswissenschaftstheorie. Tübingen: Mohr Siebeck, 2008, p. 183.

${ }^{31}$ ADEODATO, João Maurício. A retórica constitucional. São Paulo: Saraiva, 2009, p. 145, 151.

${ }^{32}$ MASTRONARDI, Philippe. Juristische Methode und Rechtstheorie als Reflexionen des Rechtsverständnisses, 2010. Available in:: www.alexandria.unisg.ch/export/DL/53445.pdf. Accessed: 10.7.2018.

${ }^{33}$ RAISCH, Peter. Vom Nutzen der überkommenen Auslegungskanones für die praktische Rechtsanwendung. Heidelberg: C. F. Müller, 1988, p. 73ss.

${ }^{34}$ MASTRONARDI, Philippe. Juristisches Denken: eine Einführung. Bern: Haupt, 2001, p. 174, 182.

${ }^{35}$ STRECK, Lenio. O que é isto - decido conforme minha consciência? Porto Alegre: Livraria do Advogado, 2010, p. 73ss. 
${ }^{36}$ RICOEUR, Paul. Teoria da interpretação: o discurso e o excesso de significação. Lisboa: Edições 70, 2000, p. 85ss.

${ }^{37}$ ZACCARIA, Giuseppe. Razón jurídica e interpretación. Cizur Menor (Navarra): Thomson Civitas, 2004, p. 185ss., p. 283ss.

${ }^{38}$ BELCHIOR, Germana P. Hermenêutica jurídica ambiental. São Paulo: Saraiva, 2011, p. 197ss.

${ }^{39}$ SANTANNA, Gustavo; HUPFER, Haide. Da impossibilidade do poder discricionário do intérprete para os hard cases no Direito Ambiental. Revista de Direito Ambiental, n. 64, São Paulo, p. 136ss., out./dez. 2011.

${ }^{40}$ MÜLLER, Friedrich. Teoria estruturante do Direito. São Paulo: RT, 2008, p. 63ss.

${ }^{41}$ MÜLLER, Friedrich; CHRISTENSEN, Ralph. Juristische Methodik - Bd. I. Berlin: Duncker\&Humblot, 2002, p. 221ss.

${ }^{42}$ BENJAMIN, Antônio Herman. Constitucionalização do ambiente e ecologização da Constituição brasileira. In: CANOTILHO, J. J. G.; LEITE, J. R. M. Direito Constitucional Ambiental brasileiro. São Paulo: Saraiva, 2007, p. 65ss.

${ }^{43}$ STÜCK, Hege. Subsumtion und Abwägung. Archiv für Rechtstheorie und Sozialphilosophie (ARSP), n. 84, Stuttgart, p. 405ss., 1998. 